\title{
Conclusion: A Discipline Viewed from the Fringes-Opportunities Taken and the Risk of Deinstitutionalisation
}

\author{
Christophe Roux
}

\section{INTRODUCTION}

The initial task we undertook when deciding to write this book was an ambitious one when compared to the existing literature. We wanted to analyse the institutionalisation of political science as an academic discipline on the basis of a genuinely detailed theoretical framework that would enable us to explore the European situation by tackling it from the 'fringes' (mostly Central-Eastern Europe) rather than from the core; and in doing so, we have opted for comparative chapters rather than the more common country-by-country exploration. This final chapter places the previous ones into a comparative perspective and draws a number of conclusions about some of the findings the authors have put together. To do so, it first relocates the discussion about political science's institutionalisation within the framework of the literature on academic disciplines. It then highlights

\footnotetext{
C. Roux ( $\square)$

University of Montpellier (CEPEL-CNRS), Montpellier, France e-mail: christophe.roux@umontpellier.fr

(C) The Author(s) 2022

G. Ilonszki, C. Roux (eds.), Opportunities and Challenges for New and Peripheral Political Science Communities, https://doi.org/10.1007/978-3-030-79054-7_9
} 
the major trends that emerge from the empirical analyses set out in the book: on the one hand, it offers a documented analysis of the discipline's development from the 1990s onwards; on the other hand, it looks at certain aspects that are of concern regarding possible precursors of the discipline's deinstitutionalisation.

\section{Political Science's Institutionalisation}

\subsection{Political Science as a Specific Field}

I do not intend to repeat here the reflections on institutionalisation already provided in Chap. 2 (by G. Ilonszki), which offers a thorough discussion of the concept and its operationalisation. The institutionalisation of political science is achieved when the discipline acquires a certain intrinsic value and meets the key requirements (identity, autonomy, stability, reproduction capacity and legitimacy) identified in the said chapter. Institutionalisation thus allows political science to be distinguished (a key element in this process) in terms of the two categories ('science' and 'political') referred to in the discipline's name.

First, as a (social) science, political science offers its own approach to politics, which involves the utilisation of specific intellectual tools and the pursuit of specific goals. It gathers data on observable facts, relies on conceptual frameworks, and follows methodological standards in order to uncover evidence supporting explanations/interpretations, in a cumulative search for knowledge that is as objective as possible. This activity is pursued in the specific institutional setting of higher education and research ${ }^{1}$ (metaphorically 'the academy'). This setting displays specific organisational patterns, norms, resources, practices and beliefs, all of which are partly shared by various countries but are also characterised by significant national idiosyncrasies. In this sense, political scientists everywhere differ from the politicians, opinion-makers, or journalists who, each in his or her own way, offer specialised knowledge and views of politics. Political scientists are not immune to interaction with these other actors operating in the sphere of politics: firstly, because political scientists operate independently from within higher

\footnotetext{
${ }^{1}$ It is important to entangle the two facets of academic activities (teaching and research) since one specificity of this sector is that scholars collectively teach the knowledge they produce themselves, even if these two types of activities sometimes rely on different institutions (see, for instance, the role of academies devoted to research vs. universities for teaching in the East-European tradition, e.g. Mongili, 1992).
} 
education and research institutions that are shaped, to varying degrees, by the policy-makers in question; and secondly, they deal with a topic-politics and political processes - in regard to which any citizen can have his or her legitimate say in a democracy.

To fulfil its mission, the format taken by political science is that of an academic discipline. Although the term 'discipline' does not merit any extensive discussion for our purposes, its meaning needs to be addressed for the sake of clarity; the reason being that the term 'discipline' is very commonly used in the academic profession without ever being defined as if it were obvious. This may be because academics writing mostly for other academics think that readers need no conceptual introduction to the matter. It is also, perhaps more importantly, because the notion of academic discipline, when carefully taken into consideration, actually appears to be more fuzzy than it seems at first. The concept is not altogether straightforward in that...it allows room for some uncertainties of application' in the words of Becher and Trowler (2006, p. 41; see also Krishnan, 2009). It appears as a contingent category: as Whitley (2000, pp. 6-7) points out, 'the academic discipline as the basic unit of social organization of knowledge production is itself historically variable... University-based disciplines are therefore only one type of knowledge production unit which unified reputational networks, employment structures, and training programmes in the late nineteenth and early twentieth centuries in many countries'. In turn, this fuzziness has an impact on the very notion of discipline, which as Trowler (2014a, pp. 1722-1723) warns, may convey an excess of 'essentialism' in that 'the category "discipline" does not have a set of essential characteristics which are all necessarily present in every instance. Secondly... each individual discipline has no essential "core characteristics" either, in the sense of being all present and identifiable at all times' (see also Trowler, 2014b). Mostly, it is because 'the sociological characteristics of disciplines often outweighed their epistemological characteristics; longevity, research funding history, and political savoir faire were found recurrently to take precedence in the academic world over the ability of a given discipline to validate knowledge or solve problems' (Donald, 2002, p. 7).

So, to put it simply, academic disciplines are indeed artefacts. These artefacts are sometimes even given ideal-typical definitions: 'a specific body of teachable knowledge with its own background of education, training, procedures, methods and content areas' according to Berger (1970, p. 24); 'a body of knowledge with a reasonable logical taxonomy, 
a specialized vocabulary, an accepted body of theory, a systematic research strategy, and techniques for replication and validation' to quote Donald (2002, p. 7). As artificial as they are, they have been taken seriously when it comes to organising the way knowledge is produced and divulged in higher education and research. This is particularly true of political science-almost a newborn discipline when compared to some of the others which boast early roots in traditional university settings. As Berger observes (1970, pp. 23-24): "the "disciplinary" framework is relatively new in the history of Western science and teaching... [and] only those sciences which appeared recently, the so-called social science group (economics, psychology, sociology, anthropology, etc.) set themselves up immediately as "disciplines".

To put it more precisely: the history of European political science has been, to a great extent, that of its struggle to become a discipline 'like the others' (and once this has been achieved-if at all-to maintain this status just like the other disciplines). Despite the premises laid down during the nineteenth century, European political science only really emerged as a result of the impetus provided by UNESCO in the late 1940s. At that time, political science institutions had been established before any robust epistemological conception of the discipline had been provided (Boncourt, 2009). Political science was founded as 'a science without scientists' (Gaïti \& Scot, 2017), to use an expression employed to depict the French situation until the late 1960s, but which is applicable to many, if not all, other national cases. It only gradually gained substance, together with an epistemological and methodological basis, through a 'learning through experience' process which accounts for much of the fluidity of the discipline's shifting borders.

As a result, political science claims to be the one discipline whose raison d'être is to deal specifically with politics, and this is the second source of its differentiation from other disciplines. It differentiates itself from other academic disciplines that are, at one and the same time, its neighbours, sources of inspiration and rivals in the quest for legitimacy and in the struggle to obtain the limited resources available within the academy. Philosophy, history, law and sociology are the most obvious examples of such other disciplines which, as several chapters of this volume show, come under the all-embracing, cross-disciplinary label of 'scientific socialism' in Central and Eastern Europe. Political science thus struggled, and continues to struggle, to preserve its own identity. Gaining the same status of discipline, 'like the others', implies another characteristic feature of the 
institutionalisation process, that is, depersonalisation, reflecting the organisational needs of any academic discipline. Indeed, just like other academic disciplines, political science relies not on one or a few individuals, but on the existence of an active community of scholars working in centres of higher education and research; furthermore, there may also be cases of self-mobilisation, such as the creation of associations (often on a national basis and possibly within the framework of international cooperation). This 'communitarian' character of the discipline is a pre-condition for the enforcement of scientific standards. The division of labour and the various facets of academic activity entail the work and judgment of more than a few individuals. This would suggest that for an academic discipline to be strongly institutionalised, it requires a 'critical mass' of scholars, and this is a persistent issue in the cases covered here, as it also is in many other European countries.

\subsection{Institutionalisation as a Specific Challenge for Political Science}

The epistemological and sociological aspects of political science are not independent features. They mutually influence each other. Moving away from the general concept of discipline to the discussion of the variety of, and differences between, disciplines is a way to tackle this issue which, in turn, affects part of the transformations it is currently undergoing.

Taken together, academic disciplines cover a vast array of knowledge without sharing the same characteristics. This point, which is made here following a series of discussions among the authors, has been touched upon only briefly herein. I would like to remind readers here of the most important things leading to a better understanding of the current challenges faced by political science.

In a seminal work that was to become highly influential (Stoeckler, 1993; Trowler, 2014b; Simpson, 2017), Anthony Biglan (1973) empirically identified three main differences among disciplines. He distinguished 
between life and non-life, ${ }^{2}$ hard and soft, ${ }^{3}$ and pure and applied ${ }^{4}$ disciplines. The second and third categories, which are the most important, were echoed by David Kolb (1981) under different labels in his distinction between 'concrete' and 'abstract' disciplines, on the one hand, and between 'active' and 'reflective' disciplines, on the other hand. Though originally thought of as forming a continuum, these categories became widely used as opposing poles of a threefold division.

In another influential work, Tony Becher and Paul Trowler (2006), following on from Becher (1994), underlined the fact that these dimensions, although important, only covered the cognitive aspects of disciplines. They claimed that a robust typology also needs to take into account the social dimension of disciplines, that is, the kinds of interaction among scholars. This led to a further two dimensions being identified, that is the 'urban' compared to the 'rural', ${ }^{5}$ and the 'convergent' as opposed to the 'divergent'. 6 The cognitive and social dimensions of academic disciplines are summed up in Table 9.1 below.

Following the same authors, these characteristics, when combined, can help us better understand the differences between disciplines in terms of the nature of knowledge, as summed up in Table 9.2.7

${ }^{2}$ Life disciplines are "concerned with life systems" while non-life disciplines "deal with inanimate objects” (Biglan, 1973, p. 202).

${ }^{3}$ Hard disciplines 'have well-developed theory, universal laws, causal propositions, they are cumulative and have generalisable findings' while soft disciplines 'have unclear boundaries, relatively unspecified theoretical structure, are subject to fashions and have loosely defined problems' (Trowler, 2014c, p. 3).

${ }^{4}$ Applied disciplines 'are regulated by external influence to some extent (for example by professional bodies such as ones regulating lawyers or engineers) and are more applied within the professions and to problems of various sorts; economic, medical, physical or social' whereas pure disciplines are 'self-regulating and not directly applied to the professions or problems in the outside world' (Trowler, 2014c, p. 3).

${ }^{5}$ Urban disciplines are 'characterized by intense interaction and a high people-to-problem ratio' while rural disciplines 'have bigger territories, less interaction and a lower people-toproblem ratio' (Trowler, 2014c, p. 3).

${ }^{6}$ Convergent disciplines 'have uniform standards in research practice and a relatively stable elite', whereas divergent disciplines 'sustain more intellectual deviance and frequently experience attempts to shift research standards' (Trowler, 2014c, p. 3 ).

${ }^{7}$ This broad picture does not account for all academic disciplines, such as the arts and other creative subjects, thus, reflecting a potential difference between 'creative' and 'empirical' disciplines; such disciplines are not forgotten, but purposely discarded, by Biglan (1973, p. 202) as being empirically unimportant, and as such are not included even if they are taught at university level. 
Table 9.1 A typology of discipline distinctiveness

\begin{tabular}{ll}
\hline Dimension & Differences \\
\hline $\begin{array}{l}\text { Cognitive } \\
\text { (Biglan, 1973; Kolb, 1981) }\end{array}$ & $\begin{array}{l}\text { Life/non-life } \\
\text { Hard/soft } \\
\text { Applied/pure }\end{array}$ \\
$\begin{array}{l}\text { Social } \\
\text { (Becher, 1994; Becher \& } \\
\begin{array}{l}\text { Trowler, 2006) } \\
\text { Urban/rural }\end{array} \\
\end{array}$ & Convergent/divergent
\end{tabular}

Source: Adapted from Trowler (2014c) and Biglan (1973)

Table 9.2 Knowledge and disciplinary grouping according to Becher and Trowler

\begin{tabular}{|c|c|}
\hline Disciplinary groupings & Nature of knowledge \\
\hline $\begin{array}{l}\text { Pure sciences (e.g. } \\
\text { physics): } \\
\text { 'hard-pure' }\end{array}$ & $\begin{array}{l}\text { Cumulative; atomistic (crystalline/tree-like); concerned with } \\
\text { universals, quantities, simplification; impersonal, value-free; } \\
\text { clear criteria for knowledge verification and obsolescence; } \\
\text { consensus over significant questions to address, now and in } \\
\text { the future; results in discovery/explanation. }\end{array}$ \\
\hline $\begin{array}{l}\text { Humanities (e.g. history) } \\
\text { and pure social sciences } \\
\text { (e.g. anthropology): } \\
\text { 'soft-pure' }\end{array}$ & $\begin{array}{l}\text { Reiterative; holistic (organic/river-like); concerned with } \\
\text { particulars, qualities, complication; personal, value-laden; } \\
\text { dispute over criteria for knowledge verification and } \\
\text { obsolescence; lack of consensus over significant questions to } \\
\text { address; results in understanding/interpretation. }\end{array}$ \\
\hline $\begin{array}{l}\text { Technologies (e.g. } \\
\text { mechanical engineering, } \\
\text { clinical medicine): } \\
\text { 'hard-applied' }\end{array}$ & $\begin{array}{l}\text { Purposive; pragmatic (know-how via hard knowledge); } \\
\text { concerned with mastery of physical environment; applies } \\
\text { heuristic approaches; criteria for judgement are purposive, } \\
\text { functional; results in products/techniques. }\end{array}$ \\
\hline $\begin{array}{l}\text { Applied social science (e.g. } \\
\text { education, law, social } \\
\text { administration): } \\
\text { 'soft-applied' }\end{array}$ & $\begin{array}{l}\text { Functional: utilitarian (know-how via soft knowledge); } \\
\text { concerned with the enhancement of [semi-] professional } \\
\text { practice; uses case studies and case law to a large extent; } \\
\text { results in protocols/procedures. }\end{array}$ \\
\hline
\end{tabular}

Source: Becher and Trowler (2006, p. 36) 
How does political science fit into this fragmented landscape? In their analysis of the Italian case, Capano and Verzichelli (2016) positioned political science as a 'soft-pure'8 discipline-thus belonging to the 'humanities and pure social science' grouping-with 'rural' and 'divergent' characteristics.

As a 'soft-pure-divergent' discipline, political science is more exposed to overt criticism than others. The specific skillset that political scientists claim to possess, and the soundness of their analysis, can be more easily questioned by the general public because of the very nature of the knowledge they produce. This is a situation that physicists, astronomers, chemists and biologists are less likely to find themselves in, if at all. Moreover, due to its specific object-politics, about which any citizen may have a say in a democracy - this questioning is even truer; even in the field of the humanities and social sciences, scholars specialised in Japanese literature or medieval history, for example, are not going to be, or are less likely to be, challenged by citizens or politicians with regard to their writings. Of course, there is nothing new about this situation. However, we paid less attention to it in 'normal' times. Changing contexts - such as the 'Great Recession', rising 'populism', or the COVID-19 pandemic-may question issues which up until now were considered resolved.

The 'rural' character of political science is not evident everywhere in Europe, although apart from a couple of substantial exceptions (the United Kingdom and Germany), it tends to be the case, and this is true not only in Central and Eastern Europe. This question is a difficult one to handle since we need to know how many political scientists are active, and how they compare to those working in other disciplines. The first item of

\footnotetext{
${ }^{8}$ These differences do not only deal with the substance of knowledge in each branch. As Neuman et al. (2002) have shown, they have implications for teaching and learning: the nature of curriculum, the way students' work is assessed, the main cognitive purposes pursued by each discipline or set of disciplines, the patterns of the collective behaviour of teaching staff, the types of teaching method or the implicit requirements for students to succeed. Belonging to the 'soft pure' family of disciplines, political science largely follows the features identified by Trowler $(2014$ b, p. 20$)$ in this regard: a 'reiterative', 'spiral' and 'holistic curriculum whose educational purposes aim at acquiring 'a broad command of intellectual ideas' and 'fluency of expression'; with 'student-centred' teaching methods to explore ideas based on discussions conducted within small groups; with time-consuming teaching preparation, a predominance of face-to-face teaching with smaller classes and limited use of information and communication technology; with a learning process in which students 'need to think laterally, read copiously and have good powers of expression, critical thinking, fluency, creativity'; finally, with assessment practices requiring 'judgment' and being partially 'intuitive'.
} 
information proved difficult to obtain, and thus raises considerable problems when comparing situations in different nations, due to the variety of norms and practices in place in each domestic academic system; the second item went beyond the resources at our disposal. Nevertheless, the general impression given is one of a small community of political scientists often struggling with problems of personnel. Academic units with too narrow a workforce can be accused of being unsustainable. For example, a too 'small' department may be seen as no longer capable of carrying on its teaching and research. While having a small structure may represent a temporary situation during a phase of institutional development, should such a situation persist, this may force the discipline to justify its existence should resources become scarce. Why does an academic department remain small? Can this be seen as evidence of its lack of appeal? Is it reasonable to keep on providing resources (premises, personnel, and so on) in a competitive context? These questions are not merely conjectural. Of course, on the other hand, the varying impact of size depends on the organisational context in which political science operates. Academic disciplines are also part of a multidisciplinary setting, such as a university and its cross-disciplinary subdivisions. This sometimes means having to deal with organisational rules that may operate as constraints running counter to the process of institutionalisation. Bearing in mind the great diversity of national situations, in a number of cases, there are formal rules that political scientists have to comply with rather than choose from, and when universities are affected by the increasingly frequent institutional changes witnessed in recent times, it is not always easy for a relatively small discipline (like political science) to have its say and safeguard its own interests. This is not a new situation, but it is one that means that the institutionalisation of political science as an academic discipline has been perhaps more challenging than that of others.

To sum up then: (a) political science is a relatively young, small discipline which has little power as far as organisational issues are concerned; (b) the nature of its knowledge (mostly soft-pure-divergent) perpetually leaves it open to overt criticism, which is both a sign of good health and also a source of exposure; (c) this feature, which is shared with other social sciences, is exacerbated by its focus on politics: in other words, an academic analysis may challenge and even upset politicians and citizens alike. For all of these reasons, even when political science develops successfully, we should not forget that its existence is never a given, but is always fragile. 
Recent years have proven this: after almost two decades of noticeable growth in the countries under scrutiny, political science seems to be encountering a number of serious challenges.

\section{Political Science on the European Fringes: SeIZING Opportunities}

The observations coming from different parts of Europe's periphery (as defined in the introduction) unsurprisingly all point to the remarkable development of political science since the 1990s. This recent process invites comments and raises a number of questions.

First of all, the emergence of political science in peripheral Europe reveals the combined importance of two macro-historical events for institutionalisation, namely to the establishment of independent statehood, and the process of democratisation. Accession to independent statehood is indeed an often taken-for-granted premise for disciplinary development. Bearing in mind the specific countries examined in this volume, a substantial number of cases are concerned. They represent the outcome of a process of independence from existing nation states, as in the case of Iceland's independence from Denmark in 1944, and Malta's independence from the United Kingdom in 1964. Or they are the result of the demise of political unions at the end of the Cold War in the 1990s. This was the case, albeit in different forms, of the collapse of the Union of Soviet Socialist Republics (giving rise to the independent states of Lithuania, Estonia, Moldova, and Belarus), of Czechoslovakia (resulting in the Czech Republic and Slovakia), and the federation of Yugoslavia (resulting, as far as the cases covered in the book are concerned, in what are now the independent states of Slovenia, Croatia, Bosnia and Herzegovina, and Serbia). While independent statehood matters, it is not per se the necessary condition for the development of political science: countries yet to gain their independence in the mid-twentieth century were able to benefit from the broader framework to which they belonged. What it does offer is the opportunity to establish an autonomous national environment for higher education and research, and within that environment, for political science. However, since these independent states derive from the break-up of broader unions, they are logically of a smaller size. All of the countries analysed here are of 
a medium or small size, which is not without consequences as the study of small states by Hlynsdóttir and Matonyte in Chap. 6 shows. Even in earlier democratic settings, smallness inhibited the development of political science for many years. And while political science in Iceland developed dramatically in the 2000s, this has not been the case with Malta, which appears a noticeable exception (it has no political science department as such, no political science journal, and no political science association).

As already mentioned in the introduction, regime change on the other hand (meaning democratisation in the cases, and for the period, covered here), appears an obvious, foreseeably powerful, factor opening the way for initiatives in this field. The political opening process witnessed in the early 1990s, paved the way for the forceful development of political science, to that the point where the subsequent decades (1990s and 2000s) appear to represent, to quote Világi, Malová and Kostova, a 'golden age' for Central-Eastern Europe ${ }^{9}$ (see Chap. 5). The aforesaid authors not only emphasise the fact that the label 'political science' became increasingly used while older labels were abandoned, and that new, appealing teaching programmes were introduced at all levels (BA, MA, and PhD). They also mention the broad implications of this political transformation. Democratisation not only allows political scientists to conduct independent research without being suspected of doing something seditious; nor does it only foster opportunities for the circulation of ideas, references, exchanges for the benefit of those political scientists willing to 'catch-up' with the most dynamic sections of the global scientific community (meaning mostly the English-speaking mainstream), possibly in keeping with the pan-European dynamics cited by Erkki Berndston in Chap. 8. It also offers an opportunity for political scientists to actively participate in the democratisation process within civil society, by observing, studying, and often publicly expounding, the events and processes emerging in the 'new Europe'. Thus the critical role played by the collapse of international communism in this entire process of democratisation cannot be underestimated.

The previous shapes of these more recently democratised states sometimes leave institutional and cultural legacies that may impact the structuring of the discipline. However, as the case of the former Yugoslavia

${ }^{9}$ Unfortunately there is no room here for a comparison of Eastern and Western Europe; in Western Europe, the same period in recent history also witnessed the substantial development of political science. 
analysed by Boban and Stanojević (see Chap. 4) shows, a shared past does not necessarily mean that newly established states will follow the same paths. These authors shed light on the differences, in terms of formal regulation (with different approaches to the organisation of higher education), financial capacity (partly reflecting the state of the corresponding domestic economies), and organisational patterns (with significant differences in terms of the space given to private institutions), that have emerged in recent decades. This is even truer of those countries previously part of the USSR: the four countries studied by Chulitskaya, Gudelis, Matonyte, and Sprincean (Chap. 3) display diverging trajectories. The case of Estonia appears, all things considered, something of a success, benefiting as this country did from a positive national environment, and from the input of one prestigious scholar from the Estonian 'diaspora' returning from the US. The same is true of Lithuania, which successfully completed the process of institutionalisation of political science. The two other states in question, on the other hand, have had to cope with a more complex situation that in fact reflects the importance of the two aforementioned features (territorial independence and democratisation). On the one hand, Moldova is affected by the territorial issue of Transnistria and its politicisation both within and outside the nation; on the other hand, Belarus continues to be suffocated by an authoritarian regime that has inhibited the development of political science within the country.

This emergence of political science as an academic discipline, since the 1990 s, in the countries examined in this volume, raises a number of questions.

First, in retrospect, it raises the question of Communism's impact and legacy in the case of those countries directly concerned (that is, all of the countries examined save Iceland and Malta). On this point, the authors concerned actually express rather divergent views. In the Soviet republics, the Communist regimes prevented the development of political science as an independent academic discipline. The label 'political science' did not exist as such in those countries, and any social sciences were mostly a form of Marxist discourse designed to legitimise a regime and to control its citizens. Historical materialism, it was said, 'is far from being the only social science... But what distinguished it from... [other] disciplines is that it is the most general science of society' (Gleserman \& Kursanov, 1968, 
pp. $\left.40-41^{10}\right)$. That particular concept of an all-encompassing science was designed as one of the tools to be used for the purposes of humanity's purported progress. As a consequence, it had to be subordinated to this ultimate goal. In the absence of political science as such, contributions to de facto political studies appeared limited and fragmented up until the 1990s. Beyond the Soviet Union, but still in Eastern Europe, the situation, as depicted by Világi, Malova and Kostova (Chap. 5), appears very similar: early pre-WWII attempts at academic reflection on politics were smothered by the 'mould-encrusted' departments of scientific socialism present in those countries, which inhibited the emergence of any form of political science. However, the same authors point to certain nuances, with limited periods (in the 1960s) of controlled 'liberalisation' in both Poland and Hungary, which appeared to be echoed (according to Boban and Stanojevic) in the former Yugoslavia during that same period. The picture portrayed is mostly one of a confirmation of the state of things (Ghica, 2020, p. 166). Unfortunately, we did not have the necessary resources to investigate two further issues that these contributions have drawn our attention to. The first such issue is the degree of substantial autonomy academics could have enjoyed during the less repressive moments in their respective countries' recent history, and the intellectual outcomes of such moments of autonomy. Secondly, regardless of what was written in that period, what was the organisational impact of the creation of departments devoted fully or partially to the study of politics? How important for the development of the discipline was the timing of their creation? It is thus clear that there is still room for further inquiry into the possible connection between these fundamentally different historical phases.

Another line of research could have followed on from the description of the unsurprising growth of political science from the 1990s onwards. However, a lack of resources prevented the authors from offering a detailed account of this transformation focusing on the manner in which political science has developed since then. The collapse of the Communist regime, representing a 'formal' legal and constitutional change in those countries concerned, resulted in political studies moving towards a more

\footnotetext{
${ }^{10}$ Though the final reference list mentions the English edition, I have used a French edition of this Russian book which has been translated into several languages. As a consequence, the page numbers are taken from the French edition I used, and may differ from the English edition.
} 
'Westernized' (an overly succinct term for what is actually a somewhat complex reality) conception of the discipline; East European political scientists were no longer obliged to toe the party line, and this in itself represented a substantial change in political science in Central and Eastern Europe. Of course, the authors do mention various organisational changes made; however, this implied the process of acquiring a new body of knowledge, set of methods, familiarity with new literature (perhaps not completely unknown to some, but in part not written in their native languages). Above all, as Boban and Stanojević point out, this also entailed 'previous' political scientists 'converting' to a 'new' political science. Unfortunately, once again we were not able to collect detailed information about this process, and thus the following questions remain unanswered: how are new criteria for academic excellence defined-basically, who would be a 'good' / employable political scientist? What would his/her expected skillset comprise? Which actors establish said skillset? Incidentally, it should be noted that the impact of Europeanisation on this process is rarely analysed. While the EU has been instrumental in reshaping the landscape of higher education and research, its impact appears as a contextual feature establishing organisational constraints and providing funding opportunities. Nevertheless, this issue has yet to be documented in any detail.

A further important aspect that is still debatable concerns the degree of institutionalisation achieved by political science at the point of its peak development at the turn of the current century. As a matter of fact, a very interesting feature of this developmental phase, as the authors reveal, is the non-linear, non-homogeneous, incomplete nature of the process' outcome. There are several tangible signs of success of course, such as the development of classes in different key subfields, the creation of academic units, the hiring of academic staff, the emergence and continued existence of journals and books, and the development of research programmes partly funded by the EU. The presence of a democratic framework (Belarus being the most significant exception) has indeed provided significant opportunities. However, as several chapters of the present work lucidly point out, there have been limits to this process: limited funding capacities, the non-linear progression of student enrolment, the incomplete achievement of generalised higher standards of scientific research, a lack of linguistic competence, and as Berndtson points out in his chapter, limited internationalisation, are all mentioned as persisting inhibiting factors. The role of those private higher education institutions present is cited as a negative factor since it implies that profit is preferred to academic quality. 
Even when the organisational aspects of the discipline seemed reinforced, through compulsory political science classes and curricula, this is not necessarily a sign of a stronger discipline, as the case of Belarus clearly shows: the resurgence of an authoritarian political agenda gave rise, in state-run universities, to the instrumental use of political science as a tool of 'indoctrination'-just like before the fall of the Berlin Wall-and as a further means of dividing academics along ideological lines.

Of course the 'catching-up' viewpoint should not be seen here as a reliable means of comparison: even in Western Europe (subsequently characterised by something of a North-South divide), the perceived satisfaction with the consolidation of the discipline coexists with disappointment regarding several aspects of academic work (e.g. the discipline's recognition, institutional development, and funding). However, in the absence of a systematic comparison, both quantitative and qualitative, of different parts of Europe, we are left with a 'glass half full' view of Central and Eastern Europe: in other words, much has been done, but much also remains to be achieved. A more robust, in-depth inquiry into the actual degree and nature of intra-European differences, in terms of the discipline's degrees of institutionalisation, still seems necessary. This impression of limited achievement is exacerbated by the analytical insights provided by the examination of the last decade or so since the so-called Great Recession, which raises concerns about the possible deinstitutionalisation of the discipline.

\section{Political Science from the 'Great Recession' to Democratic Alteration: The Perils of Deinstitutionalisation}

The essays covering the most recent period-mainly the decade following the so-called Great Recession that gradually emerged subsequent to the 2008 economic and financial crisis - tend to portray a darker picture than the light-grey landscape seen during the previous phase in the discipline's history. In that post-2008 period, the development of political science seemed to be not only limited but even actively contained (and sometimes even countered) within the broader context of political change in Europe. This raises the question of the possible deinstitutionalisation of political science- - a notion that needs to be properly defined here. Leaving aside the case of Iceland, an island located in the richest part of Europe, and that 
of Malta for the reasons given above, the next section will focus on the Central-Eastern European zone.

\subsection{Grasping Deinstitutionalisation}

The process of deinstitutionalisation, just like that of institutionalisation, merits specific consideration given that despite a 'growing rise of interest in how institutions are created, we still know relatively little about [that] process' (Dacin \& Dacin, 2008, p. 327). Deinstitutionalisation can be defined as 'the process by which the legitimacy of an established or institutionalized organizational practice erodes or discontinues' (Oliver, 1992, p. 564), that is, as merely 'the converse of institutionalization' (Philips \& Ventresca, 2008, p. 374).

In an article published in the field of management studies, Canadian scholar Christine Oliver suggests a basic scheme for understanding any deinstitutionalisation process. Deinstitutionalisation appears when the 'taken-for-granted-ness' of a given set of practices is called into question. She identifies factors of deinstitutionalisation as a set of 'pressures' falling into three distinct categories: the political, the functional, and the social. These three types of pressure operate as factors generating deinstitutionalisation. They are then reinforced by a fourth factor: this is organisational entropy, that is, the (counterintuitive) tendency of any institution to disaggregate rather than preserve its own stability, despite the institutional setting, due to actual behaviour that goes against the organisation's goals and principles. On the other hand, however, these pressures can be mitigated by a fifth factor consisting of organisational inertia. The maintenance of the status quo may be pursued for a variety of reasons (coordination requirements, the desire for predictability, psychological reluctance when faced with change) which favour institutional stability.

The combination of these factors tends to provoke the 'dissipation' ('a gradual deterioration in the acceptance and use of a particular institutionalized practice') or the 'rejection' ('a more direct assault on the validation of a long-standing tradition or established activity') of an institution (Oliver, 1992, p. 567). These factors establish the dynamics culminating in the deinstitutionalisation process itself, later translated into the 'erosion or discontinuity' of practice. The whole process can be summarised as shown in Fig. 9.1 below.

I do not intend to adopt this sequential framework as such since its fitness for our purposes is somewhat arguable. First of all, the way the main 


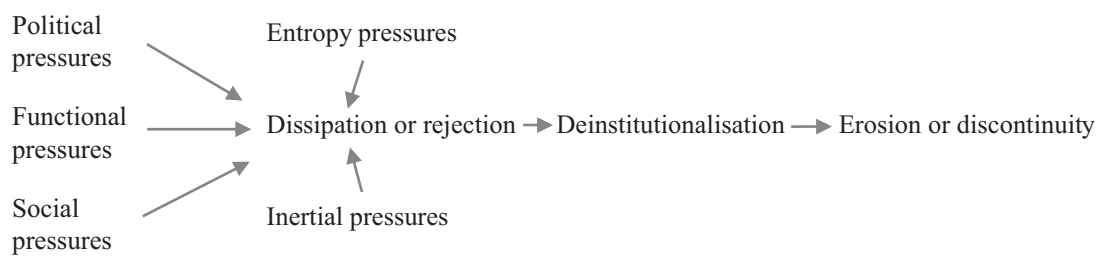

Fig. 9.1 Oliver's deinstitutionalisation process scheme. (Source: Oliver [1992, p. 567])

categories ('political', 11 'functional', ${ }^{12}$ 'social'13 pressures) were originally labelled is not always clear. Whilst these perhaps deliberately loose labels may aid a successful cross-organisation analysis (as was the author's original intent), this may become a problem insofar as only one particular type

${ }^{11}$ Political pressures essentially de-legitimise organizational practices. Internally (at the within-organization level), they include 'a growth in the criticality or representation of organizational members whose interests or beliefs conflict with the status quo; increased pressures on the organization to adopt innovative practices'. Externally (at the environmental level) they include 'a reduction in the dependence on the institutional constituents that have encouraged or enforced continuing procedural conformity with their expectations' (Oliver, 1992 , p. 568).

12 'Functional' pressures refer to 'technical or functional considerations that tend to compromise or raise doubts about the instrumental value of an institutionalized practice' (Oliver, 1992, p. 571). De-institutionalisation may be 'the consequence of changes to the perceived utility or technical instrumentality of these practices, rather than the result of interest mobilization or redistribution in organizational powers'. These changes are predicted 'to occur when institutional constituents in the environment withdraw the rewards associated with sustaining an institutionalized organizational activity; when social and economic criteria of organizational success begin to conflict significantly with one another; and when the organization experiences an increase in its technical specificity or goal clarity'. They may also be linked to 'environmental changes' when 'intensified competition for resources and the emergence of dissonant information or unexpected events in the environment that directly challenge the advisability of sustaining an institutional activity'. The very sense of the institution is criticized on economic and technical grounds, rather than on 'political' grounds.

13 'Social' pressures refer to those where organizations 'are neither pro-active agents of deinstitutionalization nor centrally intent on abandoning or rejecting particular institutional traditions' (Oliver, 1992, p. 575). They include 'increasing normative fragmentation within an organization as a by-product of other organizational changes (increasing workforce diversity, high turnover...); disruptions to the organization's historical continuity (such as mergers); changes in state laws or societal expectations that prohibit or discourage the perpetuation of an institutional practice; and structural changes to the organization or the environment within which the organization resides that disaggregate collective norms and values' (Oliver, 1992 , p. 575), for example geographical fragmentation. 
of organisation, such as political science as an academic discipline, is concerned. Moreover, there is the risk that the categories may overlap. As we will see, something presented as a 'functional' pressure may be the reformulation of a 'political' pressure in disguise; the very same can be said about 'social' pressures, which need to be channelled through a political/ administrative decision-making actor or set of actors in order to become effective. As a consequence, whilst Oliver's contribution is a stimulating attempt to clarify the concept of deinstitutionalisation, and to disentangle its constitutive dimensions, her labels need to be rearranged. ${ }^{14}$ I will limit myself here to considering the generating factors of deinstitutionalisation in Central and Eastern Europe.

As far as 'causal' mechanisms of deinstitutionalisation are concerned, I suggest it is possible to identify a tentative, non-exhaustive set of factors that may be at work in relation to the discipline. This belief is based on a series of convergent observations set out in various chapters of the present work. They signal a number of difficulties political science is facing nowadays in the countries under scrutiny. While none of the authors actually suggests that the very existence of political science as such is at risk, they have gathered enough information suggesting that the discipline may be affected, at the very least, by 'antecedents of deinstitutionalization' (Oliver, 1992). This volume also shines some light on other important aspects which would also point to the deinstitutionalisation process analysed by Oliver. They comprise a series of pressures concerning policy reforms, and other direct ideological pressures within the context of a growth in 'illiberal' democracies.

\subsection{Functional Pressures: The Lack of Financial Resources}

Financial resources are indispensable if institutions are to work. In recent years many academic institutions have been faced with challenges in this

\footnotetext{
${ }^{14}$ The same can be said about the possibility of drawing a clear-cut line between internal (intra-organisational) and external (organisation-environment) levels. The extent to which an academic discipline can be considered as an organisational unit is not easy to grasp. In fact, an academic discipline does not take one single formal shape, especially when one considers all aspects of academic activity (teaching, research and the divulgation of research findings among the general public, administrative services, etc.). On the contrary, it consists of a set of embedded actions and institutions whose organisational features vary across dimensions and from one national context to another. They are characterised by varying degrees of autonomy.
} 
regard. However, an improvement accompanied the development of the discipline from the 1990s onwards. Basic domestic public funding was supplemented by the adoption of contract-based research through European programmes (e.g., Horizon, 2020 and its predecessor framework-programmes) and national programmes, either public (often), private, or a mix of both. This paved the way for more ambitious research programmes on the one hand, but it also prioritised competitive rules over the distributive principle on the other. In this game, the opportunities given to political scientists have been rather unevenly distributed since overall, Central and Eastern European scholars are more often participants in, rather than coordinators of, European projects. The 'discovery' of this new type of funding does not regard CEE only: in Western Europe as well, not all countries were familiar with these competitive schemes.

The so-called Great Recession created a situation of financial stress that affected many states, with higher education and research being particularly impacted by the consequent reduction in public spending: in fact, higher education and research rely heavily on public funding, as the COST national reports show. When this circumstance has not led to automatic budget reductions, it has nevertheless increased competition for funding. Again, this situation goes beyond the bounds of Central and Eastern Europe, where there have been many cases of cuts in funding, together with notable exceptions in some countries (Poland and Lithuania for instance) (EUA, 2017, 2020). Signs of short-time recovery were observed before the COVID-19 crisis hit the continent at the European level (EUA, 2020), albeit with considerable disparities among countries. It is too soon to gauge the real impact of the current pandemic (Autumn, 2020), although there are good reasons to be worried. The current situation further exemplifies the broader challenge faced by higher education and research. Marek Kwiek (2017) convincingly reminds us of the situation universities have been facing for years: they have moved gradually from an age of relative abundance in the post-war decades, to a situation of permanent austerity in which higher education and research is only one contender for public resources among many legitimate, powerful ones, especially as far as welfare state provisions (public health and pension systems) are concerned. As a consequence, in a game strongly influenced by international organisations (the OECD, the World Bank, the IMF), the higher education sector cannot expect its needs to be automatically satisfied. The COVID-19 crisis, whose damaging effects are being tentatively contained by European states through massive funding, is likely to 
exacerbate this predicament. In turn, the consequences of this transformation are likely to have repercussions on the competition for resources within the academy. Despite the fact that a social science like political science has relatively limited needs compared to hard sciences, the sword of Damocles remains.

This constraining context is more fully understood when considering two other sources of pressures that the present authors have identified: policy and political pressures.

\subsection{Policy and Political Pressures: Why Political Science?}

I feel comfortable with dropping the notion of 'social pressure', which may sound too vague and fuzzy. I would prefer to talk about 'policy pressures', even though this is not an unproblematic label, and is proposed here in a tentative manner only. It aims to indicate the set of external rules that derive from the pressures coming (in part at least) from outside academia. These may reflect, or be advocated in support of, societal needs. This regards, in particular, the growing need for political science, like other social sciences and the humanities, to prove its 'social utility', its capacity to provide students with the required knowledge and skills to enter the job market and its positive economic and social impact on markets and society as a whole. The very wording of the latter sentence illustrates the shift in focus of higher education and research in recent decades.

Several chapters of the present work shed light on the situation of political science in Central and Eastern Europe. The authors concerned do not take the discipline's appeal for students for granted. If political science was relatively successful at first, it was for a series of reasons that included instrumental calculations. On the one hand, it may have benefited from a fashionable image and met students' desire to gain a better understanding of politics and society in the new pluralistic landscape. On the other hand, however, studying political science was seen as a way of obtaining a degree without too much difficulty. Demand was not that strong, given that Central and Eastern Europe has been a demographically depressed zone since the 1980s - with limited exceptions such as Poland and Lithuania (Adveev et al., 2011). Nonetheless, young people have been seen as an object of contention, and political science (along with other disciplines including law) has been accused of depriving certain sectors seen as key for the economy (the automotive industry for instance) of the necessary workforce. Hence the lobbying actions and higher education policy 
instruments designed to strengthen support for those sectors to which political science is seen as unable to contribute.

Such technical disputes should not be too sharply dissociated from the way the authors have addressed another issue, namely the fact that political science is targeted as a political inconvenience. They have documented the rise in ideological pressures reflecting authoritarian trends that are affecting higher education and research as well. It has been suggested that the current period is marked by a global wave of 'autocratization' which has not spared Europe, affecting as it has Hungary and Poland first and foremost (Sata \& Karolewski, 2020), but also other areas of Central and Eastern Europe (Cianetti et al., 2018). This phenomenon has been largely fuelled by democratic erosion, that is, when leaders "legally access power and then gradually, but substantially, undermine democratic norms without abolishing key democratic institutions" (Lührmann \& Lindberg, 2019 , p. 1105). Academic freedom in research and teaching in general, and in political science in particular, is likely to become increasingly fragile in such a context. Several authors agree that this threat is not only a potential one. The attacks on political science have taken different forms in the 2010 s but were not totally unprecedented. Sometimes these attacks have consisted in a frontal assault on political science as such, due to its alleged political commitments. Scientific neutrality is alleged to be a cover up for propaganda through academic channels. For instance, the labelling of a party as populist, nationalist, or extremist, or of the state of the regime and its exposure to authoritarianism, becomes a pretext to criticize it. In other cases, societal issues are at stake, as shown by the way gender studies are considered and even counter-attacked. Sometimes the attacks are also of an indirect nature: instead of criticising academics on ideological grounds, the critical discourse undermines the relevance of disciplines such as political science, which are depicted as needless and ill-suited to satisfying the economic priorities of the job market. All the features that Albert O. Hirschman (1991) listed years ago in his analysis of reactionary discourse are recognisable here. Using Hirschman's terms, political science and similar disciplines would, respectively, render the economic dynamic of societies more fragile (jeopardy), weaken its underlying societal values (perversity), and appear as both useless and resource-consuming activity (futility). All these elements are likely to weaken several dimensions of the institutionalisation process identified by Ilonszki in Chap. 2: they undermine the discipline's legitimacy from without, they question its autonomy, they make its identity more fragile; and this, in turn, could damage its 
stability and reproduction. All of these features could be seen as pointing to actual antecedents of deinstitutionalisation. However, they occur in a similar way to that in which authoritarian trends develop, that is gradually mirroring democratic erosion: the academic construction is attacked one piece at a time rather than suffering a massive shutdown. Is this situation specific to Central and Eastern Europe? It is perhaps more a matter of intensity than of nature since Europe as a whole has shown signs of concern on that front (Paternotte \& Verloo, 2020).

\section{Conclusion}

The picture emerging from our inquiry into the diversity of European political science, and in particular into its institutional settings, offers a more nuanced view of the discipline's development than was previously held. If the development of political science in Europe in the long run has been successful, this is only so to a limited extent. The state of the discipline cannot only be accounted for by examining the more privileged area of North-Western Europe. The exploration that the authors have made in this collection of essays offers a more realistic view of the state of political science. It tells us not only about its success but also about its limits and accompanying threats. Once again, it should be underlined that this task has been accomplished without financial support. The authors in question have managed to produce data notwithstanding the situation in which they found themselves characterised by the strikingly poor monitoring of the discipline in general. It can only be hoped that this book will have further contributed towards bridging the information gap in this field, which at the present period in time could prove invaluable.

\section{REFERENCES}

Adveev, A., Eremenko, T., Festy, P., Gaymu, N., Le Bouteillec, N., \& Springer, S. (2011). Populations and Demographic Trends of European Countries (1980-2010). Population [English edition], 66(1), 9-133.

Becher, T. (1994). The Significance of Disciplinary Differences. Studies in Higher Education, 19(2), 151-161.

Becher, T., \& Trowler, P. T. (2006). Academic Tribes and Territories. Intellectual Enquiry and the Culture of Disciplines (2nd ed.). The Society for Research into Higher Education \& The Open University Press. 
Berger, G. (1970). Opinion and Fact. In OECD, Interdisciplinarity: Problems of Teaching and Research in Universities (pp. 19-74). OECD.

Biglan, A. (1973). The Characteristics of Subject Matter in Different Academic Areas. Journal of Applied Psychology, 57(3), 195-203.

Boncourt, T. (2009). A History of the International Political Science Association 1949-2009. The International Political Science Association.

Capano, G., \& Verzichelli, L. (2016). Looking for Eclecticism? Structural and Contextual Factors Underlying Political Science's Relevance Gap: Evidence from the Italian Case. European Political Science, 15(2), 211-232.

Cianetti, L., Dawson, J., \& Hanley, S. (2018). Rethinking "Democratic Backsliding" in Central and Eastern Europe: Looking Beyond Hungary and Poland. East European Politics, 34(3), 243-256.

Dacin, M. T., \& Dacin, P. A. (2008). Traditions as Institutionalized Practice: Implications for De-Institutionalization. In R. Greenwood, C. Oliver, R. Suddaby, \& K. Sahlin-Andersson (Eds.), The Sage Handbook of Organizational Institutionalism (pp. 326-352). Sage.

Donald, J. T. (2002). Learning to Think: Disciplinary Perspectives. Jossey-Bass.

EUA. (2017). Public Funding Observatory: Report 2017. European University Association.

EUA. (2020). Public Funding Observatory: Report 2019/20. European University Association.

Gaiti, B., \& Scot, M. (2017). A Science Without Scientists: The Paradoxes of the Emergence of Political Science in France, 1945-68. Revue Française de Science Politique [English ed.], 67(1), 13-42. https://doi.org/10.3917/ rfsp.671.0013.

Ghica, L. A. (2020). From Imagined Disciplinary Communities to Building Professional Solidarity. Political Science in Postcommunist Europe. In T. Boncourt, I. Engeli, \& D. Garzia (Eds.), Political Science in Europe. Achievements, Challenges, Prospects (pp. 159-178). Rowman \& Littlefield.

Gleserman, G., \& Kursanov, G. (Eds.). (1968). Historical Materialism: Basic Problems. Progress Publishers.

Hirschman, A. O. (1991). The Rhetoric of Reaction. Perversity, Futility, Jeopardy. The Belknap Press of Harvard University Press.

Kolb, D. A. (1981). Learning Styles and Disciplinary Differences. In A. W. Chickering (Ed.), The Modern American College. Responding to the New Realities of Diverse Students and a Changing Societies (pp. 232-255). Jossey-Bass.

Krishnan, A. (2009). What Are Academic Disciplines? Some Observations on the Disciplinarity vs. Interdisciplinarity Debate. ESRC National Centre for Research Methods Working Paper 3, January, 59 p. 
Kwiek, M. (2017). Higher Education, Welfare States and Austerity: Pressures on Competing Public Institutions. In J. Nixon (Ed.), Higher Education in Austerity Europe (pp. 33-45). Bloomsbury.

Lührmann, A., \& Lindberg, S. I. (2019). A Third Wave of Autocratization Is Here: What Is New About It? Democratization, 26(7), 1095-1113.

Mongili, A. (1992). Les institutions scientifiques soviétiques à l'heure de la Perestrojka [Soviet Scientific Institutions at the Perestroika Moment]. Cabiers du Monde Russe et Soviétique, 33(2-3), 223-242.

Neuman, R., Parry, S., \& Becher, T. (2002). Teaching and Learning in their Disciplinary Contexts: A Conceptual Analysis. Studies in Higher Education, 27(4), 405-417.

Oliver, C. (1992). The Antecedents of Deinstitutionalization. Organization Studies, 13(4), 563-588.

Paternotte, D., \& Verloo, M. (2020). Political Science at Risk in Europe. Frailness and the Study of Power. In T. Boncourt, I. Engeli, \& D. Garzia (Eds.), Political Science in Europe. Achievements, Challenges, Prospects (pp. 287-310). Rowman \& Littlefield.

Philips, N., \& Ventresca, M. (2008). Deinstitutionalization. InS. Clegg \& J. R. Bailey (Eds.), International Encyclopedia of Organization Studies (pp. 374-376). Sage.

Sata, R., \& Karolewski, I. P. (2020). Caesarean Politics in Hungary and Poland. East European Politics, 36(2), 206-225.

Simpson, A. (2017). The Surprising Persistence of Biglan's Classification Scheme. Studies in Higher Education, 42(8), 1520-1531.

Stoeckler, J. L. (1993). The Biglan Classification Revisited. Research in Higher Education, 34(4), 451-464.

Trowler, P. T. (2014a). Depicting and Researching Disciplines: Strong and Moderate-Essentialist Approaches. Studies in Higher Education, 39(10), 1720-1731.

Trowler, P. T. (2014b). Disciplines and Interdisciplinarity. Conceptual Groundwork. In P. Trowler, M. Saunders, \& V. Bamber (Eds.), Tribes and Territories in the 21st Century Rethinking the Significance of Disciplines in Higher Education (pp. 5-29). Routledge.

Trowler, P. T. (2014c). Academic Tribes and Territories: The Theoretical Trajectory. Osterreichische Zeitschrift fur Geschichtswissenschaften, 25(3), 17-26.

Whitley, R. (2000). The Intellectual and Social Organization of the Sciences. Oxford University Press. 
Open Access This chapter is licensed under the terms of the Creative Commons Attribution 4.0 International License (http://creativecommons.org/licenses/ by $/ 4.0 /$ ), which permits use, sharing, adaptation, distribution and reproduction in any medium or format, as long as you give appropriate credit to the original author(s) and the source, provide a link to the Creative Commons licence and indicate if changes were made.

The images or other third party material in this chapter are included in the chapter's Creative Commons licence, unless indicated otherwise in a credit line to the material. If material is not included in the chapter's Creative Commons licence and your intended use is not permitted by statutory regulation or exceeds the permitted use, you will need to obtain permission directly from the copyright holder. 